\title{
Working-class Organizations and Alternative Economic Discourses: Evidences on the Socialization and Demobilization of Spanish Urban Workers
}

\author{
Anna Carrillo Arnal \\ University of Missouri-Columbia
}

How to cite this paper: Arnal, A. C. (2019). Working-class Organizations and Alternative Economic Discourses: Evidences on the Socialization and Demobilization of Spanish Urban Workers. The Educational Review, USA, 3(12), 200-214.

http://dx.doi.org/10.26855/er.2019.12.002

*Corresponding author: Anna Carrillo Arnal, University of Missouri-Columbia.

E-mail: acfh7@mail.missouri.edu

\begin{abstract}
Based on qualitative interviews, participant observation and archival research, this article tests the importance of labour organizations in workers' development of a complex understanding of the economic system. More concretely, it offers a comparison of the discourses of Spanish urban workers with different levels of participation in these organizations. Then, this study presents an apparent paradox, the very same alternative economic discourse that allows workers to challenge the dominant economic discourses acts as an element of demobilization. What is more, the article reveals that the lack of renewal within neighbourhood organizations and neighbourhood leaderships, and the prevalent use of the rhetoric of the 1970s labour movement are at the core of this demobilization.
\end{abstract}

\section{Keywords}

neighborhood organizations, discourse, economic system

\section{Introduction}

The transition from industrial capitalism to monopoly capitalism has involved a considerable increase of social inequalities both between and within countries (Aglietta, 2015; Hardt \& Negri, 2001; Baran \& Sweezy, 1966). This divergence of incomes and of opportunities is expected to reach a historic maximum in the twenty-first century, affecting the distribution of wealth and, consequently, the social structure (Domhoff, 2014; Piketty, 2014).These changes in the economy have been praised and supported by neoliberalism, a theory of political economic practice that presents deep structural inequalities and problems as moral and individual issues (Harvey, 2005; Bourdieu, 1998). In this context, the working class does not only face a decline in their living and working conditions, and life opportunities, but is also affected of a heightened stigmatization, which is key in the maintenance of class exploitation (Wacquant, 2008). For these reasons, it is important to pay attention to the working class' understanding of the economy and of their position and role in a globalized economic system, as well as to the institutions that shape these economic views.

The main objective of this article is to present the role of the traditional organizations of the labour movement - especially unions, left parties, and neighbourhood organizations - in the shaping of workers' economic discourses. This article is part of a larger project that studied Spanish urban workers' resistance to dominant economic discourses and their development of alternative, pro-worker, explanations for their economic situation. This larger project revealed that these traditional organizations, especially neighbourhood organizations, were key for the development of a counter-hegemonic discourse in the studied community. Based on qualitative interviews, participant observation and archival research, this article tests the importance of labour organizations in workers' development of a complex understanding of the economic system. More concretely, it offers a comparison of the discourses of Spanish urban workers with different levels of participation in these organizations. Then,this study presents an apparent paradox: the very same alternative economic discourse that allows workers to challenge the dominant economic discourses acts as an element of demobilization. What is more, the article reveals that the lack of renewal within neighbourhood organizations and neighbourhood leaderships, and the prevalent use of the rhetoric of the 1970s labour movement are at the core of this demobilization. 


\section{Literature review}

Henry Giroux (2018) has observed that any form of working-class resistance requires a critical and historical reflection on the repressive mechanisms used by the ruling elites. According to Giroux, in order to reclaim their agency in history, the working class must "flip the script". This process consists of refusing the scripts that define the working class by their deficits, and which lead to the depoliticization of social inequalities. In contrast, he encourages stressing those aspects that provide workers with a sense of dignity, worthiness and of "working class courage" (Giroux, 2018, p.10). Giroux refers to narratives, historical memories, daily rituals and social relationships that foster working class agency and resistance. In this article, it is argued that traditional working-class organizations, such as the labour union and the workers' party, play an essential role in providing workers with an alternative understanding of the economic system and of their position on it.

Previous literature has pointed out to the workers' party as a key agent for the socialization of the working class. In fact, research suggests that support for workers' parties is a key socio-political foundation of socialist values (Campbell, 2015). The young branches of the workers' party may be particularly able to engage young workers. Hughes (2012) studied the experiences of a group of working-class young men who participated in a branch of the Labour Party Young Socialists (UK) in the 1960s. The branch, a small Trostkian group, provided workers with political education, in a process similar to that experienced by well-off young activists at private universities. This organization "served significant social, cultural and psychological functions" (Hughes, 2012, p.173), helped the young menmake sense of their environment and develop a working-class identity tied to their locality, cultural repertoires and emotional memories. It also fostered a collective identity as 'socialist working men'. Working-class sport clubs played a similar role in the socialization of the young workers. For instance, Keskinen (2011) has documented the political socialisation that took place in Finnish working-class sports clubs during the years 1903-1923. In these clubs, workers learned about socialism and about the traditions of the working class.

Another privileged agent of socialization is the labour union. Studying French syndicalism in its golden age - the two decades before the First World War - Leberstein (1999) concluded that the labour unions' educational project succeeded in encouraging a class identity and a class consciousness, and in politicizing all aspects of French culture. Leberstein regreted, however, that this socialization process had not been strong enough to prevent the war and the militarization of workers.

In a different context, a study across a plurality of African countries has suggested that, in their quest against neoliberal policies, labour unions may also advance processes of democratization as they contribute to the political socialization of their members, instructing them on the mechanics of civil engagement (Karreth, 2018). Furthermore, individuals who are affiliated with a labour union, especially those who self-identify as "at the left", hold more tolerant views regarding immigration than those individuals who are not members of a union (Martín \& Molina, 2014).

Previous literature has also stressed the importance of the factory and the floor plant for workers' reproduction of or resistance against capitalism and the organization of production (Hakken, 1980). In an acclaimed study, Burawoy (1979) suggested that workers' reproduction of capitalism does not depend of previous values that come from the education system, the family, the church, etc., but that it takes place in the factory floor due to a particular organization of the production system. According to Burawoy, previous values are only useful in times of change when they are used as ideologies. Thus, workers "learn to labour" and actively participate in the reproduction of a system that exploits them.

Burawoy's research, however, is not without contestation. Cotgrove and Vamplew (1972) studied the industrial and political attitudes of workers in five different highly automated oil or chemical processing plants in the United Kingdom. They found that, although the in-plant situations were very similar, workers would display very different political attitudes depending on values acquired outside the factory. Likewise, Yücesan-Özdemir (2003) did not find consensual relationships in the factory floor. Studying workers in an automobile factory in Turkey, the scholar showed that workers developed counter-hegemonic discourses and resistant subcultures to challenge managerial strategies. These hidden transcripts, however, did not lead to an open class resistance nor did they prevent the reproduction of the capitalist production process.

Recent research has revealed that poorer workers may also benefit from socialization processes that take place in grassroots food banks. Gómez, Carbonero, and Viladrich (2018) discovered that grassroots food banks provide users with an alternative discourse that helps them to challenge the stigma associated with poverty and charity relationships. The alternative discourse also allows them to identify the structural causes of their tough situation. This discourse opposes hunger as a social justice issue within a framework of rejection of capitalism and of market relations. Thus, 
food becomes a token for a broader political activism, in which the users of the food banks also participate. Participation in grassroots food banks also leads to the development of interpersonal and political solidarity, and users feel that they do not need to be ashamed nor grateful for receiving food because they have the right to it. Although this initiative does not lead to the eradication of food injustice, it contributes to developing a neighbourhood-based solidarity and to making people in situations of poverty active members of their communities.

Doing research in Israel and the United States, Wandersman et al. (1987) found that rootedness in the community is actually associated with political and civic participation. Contrary to previous research, they proved that lower levels of education and lower occupational status were no deterrents of participation. Wandersman et al. (1987) ventured that this is due to the importance for working-class communities of the neighbourhood organizations and block organizations. In order to encourage neighbours' mobilization and legitimize their own agendas, these organizations develop "place frames", motivating discourses that refer to the living conditions in the neighbourhood and to the everyday life experiences of the residents. These frames foster a neighbourhood identity that underplays social differences and unites residents in neighbourhood projects and activities. Thus, neighbourhood organizations can be considered part of "contentious politics (Martin, 2003).

However, neighbourhood organizations have actually achieved low levels of representative democracy and of participatory democracy. In fact, they increasingly become elitist groups with strong ties with the local administration, resulting on their exertion of social control over neighbours. The iron law of oligarchy would also explain the appearance of racist and reactionary tendencies in neighbourhood organizations that, on the other hand, do provide essential services for their communities (Cnaan, 1991). Similarly, Scholte (2013) argues that labour unions, among other civil society organizations, have failed to mobilize activism to reshape financial markets. In contrast, business forums, such as business associations, and economic policy research institutes have been very active promoting their neoliberal agenda. One of the main reasons behind this lack of mobilization is, according to Scholte, citizens' widespread lack of knowledge on finance capital and its functioning. Another relevant reason is the existence of a powerful neoliberal discourse that encourages the globalization and liberalization of financial markets and prevents other alternative political imaginations. This discourse is mostly championed by universities and capitalist organizations. However, some working-class organizations are becoming embedded of the neoliberal language, trumping their ability to mobilize and present alternative discourses (Gough, 2002). Scholte's (2013) recommendation to overcome this situation is increasing the education and awareness of the civil society regarding the functioning of the financial system.

\section{Methodology}

The fieldwork for this study was conducted in the working-class neighbourhood of La Verneda-Sant Martí (Barcelona, Spain), between February 2016 and January 2017, and involved thirty in-depth interviews with urban workers from different background and occupations. The interviews lasted a mean of 1:25 hours and were audiotaped. In order to triangulate the data, interviews were conducted in different areas of the neighbourhood, and in different public and private spaces such as bars, private homes, job places and at different organizations in the neighbourhood. Likewise, the interviews were complemented with archival research on the history of the neighbourhood in the Historic Archive of Barcelona, the Photographic Archive of Barcelona and San Martín District Archive. Biographies, historic accounts of social movements, as well as news from two historic newspapers, La Vanguardia and El Diario de Barcelona, were also considered. Archival research allowed the researcher to better contextualize and double-check the explanations of the interviewees.

The fieldwork also involved participant observation in several organizations of the neighbourhood, in neighbourhood meetings, and in popular activities (festivities and popular walks, among others). Besides formal participant observation, the fieldwork entailed thousands of informal conversations with the residents of the neighbourhood.

All observations were registered in a field-work diary.

Table 1. Participant observation instances

\begin{tabular}{llll}
\hline Activity & Dates & Time & Place \\
\hline Participation in a financial & March the 1st. to June 7th, & Tuesdadys, 19-21h & $\begin{array}{l}\text { Adults School of La Verneda- } \\
\text { Sant Marti }\end{array}$ \\
literacy class & 2016 & & Adults School of La Verneda- \\
Part time job, doing administrative & March 10th. to May 15th, & Mon-Fri, & Sant Marti \\
\hline work and some classes & 2016 & $9: 00-14: 00$ & Sa
\end{tabular}


table1. cont.

\begin{tabular}{|c|c|c|c|}
\hline Activity & Dates & Time & Place \\
\hline $\begin{array}{l}\text { Volunteer at the Saint } \\
\text { George Day fair }\end{array}$ & April 23rd, 2016 & $15 \mathrm{~h}-21 \mathrm{~h}$. & Street \\
\hline $\begin{array}{l}\text { "Celebration of the } 50 \text { years of } \\
\text { La Pau", talk organized by the } \\
\text { Neighbors' Organization Sant } \\
\text { Marti de Provencals }\end{array}$ & May 11th 2016 & 19h- 20:30h. & $\begin{array}{l}\text { Headquarters of the neighbors } \\
\text { organization Sant Marti de } \\
\text { Provencals and the Historical } \\
\text { Archive of Sant Marti }\end{array}$ \\
\hline $\begin{array}{l}\text { Popular walk. "Below zero". } \\
\text { Organized by the Adults School } \\
\text { of La Verneda- Sant Marti and } \\
\text { the Studies Society of La } \\
\text { Verneda of Sant Marti. }\end{array}$ & June 15th 2016 & $17: 30 h-19 h$ & Street \\
\hline $\begin{array}{l}\text { Meeting of the People's } \\
\text { Assembly of Sant Marti }\end{array}$ & June 26th 2016 & $19 \mathrm{~h}-20: 30 \mathrm{~h}$ & $\begin{array}{l}\text { Popular Athenaeum of Sant } \\
\text { Marti }\end{array}$ \\
\hline $\begin{array}{l}\text { Popular lunch of the People's } \\
\text { Assembly of Sant Marti }\end{array}$ & July 2nd 2016 & $14 h-16 h$ & $\begin{array}{l}\text { Popular Athenaeum of Sant } \\
\text { Marti }\end{array}$ \\
\hline $\begin{array}{l}\text { Meeting of the People's } \\
\text { Assembly of Sant Marti }\end{array}$ & November 8th, 2016 & 19h-21h. & $\begin{array}{l}\text { Street, corner between } \\
\text { Guipuzcua and Cantabria } \\
\text { streets }\end{array}$ \\
\hline $\begin{array}{l}\text { Presentation by two Colombian } \\
\text { peasants of the project "Peasant } \\
\text { Reservation Areas", organized by } \\
\text { the Anti-imperialist committee } \\
\text { of the People's Assembly of Sant } \\
\text { Marti in solidarity with the } \\
\text { Colombian peace process }\end{array}$ & November 9th, 2016 & $19 \mathrm{~h}-20: 30 \mathrm{~h}$ & $\begin{array}{l}\text { Popular Athenaeum of Sant } \\
\text { Marti }\end{array}$ \\
\hline $\begin{array}{l}\text { Presentation of the book "Siria is } \\
\text { the center of the world" of Jose } \\
\text { Antonio Egido. Organized by the } \\
\text { People's Assembly of Sant Marti } \\
\text { and the Popular Unitary Platform } \\
\text { against the War and against NATO }\end{array}$ & November 12th, 2016 & $18 \mathrm{~h}-21: 45 \mathrm{~h}$. & $\begin{array}{l}\text { Popular Athenaeum of Sant } \\
\text { Marti }\end{array}$ \\
\hline $\begin{array}{l}\text { Multiple informal observations and } \\
\text { interactions in the neighborhood }\end{array}$ & Feb. - Nov. 2016 & & \\
\hline
\end{tabular}

The discourses of the interviewees were analysed with support of the software Atlas.ti for qualitative data analysis. A qualitative discourse analysis was carried out using 140 codes that emerged from the interviews. The materials from participant observation (notes, leaflets, posters, etc.) were coded on hand using the same codes.

\section{Context}

In order to understand workers' discourses and the socializing role of working-class organizations, one must first pay attention to the economic and political changes in Spain, Catalonia, and the specific neighbourhood from the 1940s until the present day.

The Spanish Civil War ended on 1939 with the victory of the fascist troops of Francisco Franco, and lasted for thirtysix years, until the death of the dictator in 1975. In this context, workers' and democratic organizations were forced into hiding. Accepting that the war was lost, the communist parties Unified Socialist Party of Catalonia (PSUC) and 
Communist Party of Spain (PCE) moved into political action for the improvement of the living conditions of the working class, which was suffering the extreme poverty of the post-war era (Kaplan, 1980; Lardín, 2007). From the 1960s on, the PSUC and the PCE also stood out for their political opposition to the dictatorship. The PCE, which was close to the labour movement and also secretly controlled the bases of Franco's Vertical Syndicate, became the main referent against the Francois regime (Kaplan, 1980; Témime, Broder, \&Chastagnaret, 1995).

The late 1940s were characterize by labour unrest and struggles. Urban workers, who were living and working in very poor conditions, had shown, until then, a passive hostility towards the regime. However, the constant abuses of employers, and the perception that their situation would not improve in their future due to the strong consolidation of fascism, led to mobilizations (Lardín, 2007; Témime, Broder and Chastagnaret, 1995). In Barcelona, the largest mobilizations were associated with the textile, the chemical, and the metallurgical industries. One of the main popular protests actually occurred in Barcelona. In March 1951, the city authorities arbitrarily raised the price of the streetcar ticket. Workers responded with a boycott against the streetcar company. The boycott led to the first strike after the Civil War and to many different protests and mobilizations in the city against the Francois authorities (Venteo, 2011). Boycotts and strikes continued during the 1950s in different regions of Spain. Besides fighting for better working conditions, workers' mobilizations also had an anti-fascist character.

From 1959 until 1973, Spain experienced a period of quick economic growth that is popularly known as "the Spanish miracle" (Kaplan, 1980). Economic development was not paired with social and political improvements. The regime kept its rigid ultraconservatism in politics, which clashed in occasions with economic growth, and prevented the significant improvement of the living conditions of the population. This led to more strikes and workers' mobilizations. In Madrid and Barcelona, workers organized in Workers' Commissions that constituted an independent and democratic movement that fought in two fronts. On the one hand, they led workers' organization and mobilization in the workplace for the improvement of working conditions. On the other hand, they led the political struggle for the achievement of civil rights and the legalization of unions (Témime, Broder and Chastagnaret, 1995). It is in this same timeframe, and especially at the beginning of the 1970s, when urban workers started organizing themselves in neighbourhood organizations for the improvement of their living conditions (Castells, 1983).

In November 1975, Franco died. His death marks the beginning of the period of transition to democracy, called "la Tranisición" (the Transition). June 1977, Spain celebrated elections to the constituent Courts. The elections were won by the Union of Democratic Center (UCD), a party which consisted of reformist fascists, Christian democrats, and some liberals. This period was followed by the Spanish Socialist Workers' Party (PSOE), which remained in power for thirteen and a half years, until 1996. The Communist Party of Spain, despite its influence during the clandestine opposition to the dictatorship and its relevant involvement in the Transition, did not survive democracy. In the election of 1982 , it only got $3.28 \%$ of the valid votes, and never recovered its influence.

During democracy, political parties and unions have multiplied. Two political parties have governed, the Popular Party, a conservative and right-wing party, and the already-mentioned Spanish Socialist Workers' Party. There are two main labour unions: the Workers' Commissions, linked to the Communist Party of Spain, and the General Union of Workers, linked to Spanish Socialist Workers' Party; as well as many smaller independent unions, such as the anarchist General Confederation of Labour.

The neighbourhood of La Verneda - Sant Martí belongs to Barcelona, which is the capital of a region called Catalonia and the second largest city of Spain. The village of Sant Martí de Provençal, the heart of the neighbourhood, became annexed to the city of Barcelona in 1897. It was mainly constituted by cropland. The southern portion of the neighbourhood also contained a large number of factories that gave the area the name of the "Catalan Manchester". The village was comprised of industrial workers, mostly from the textile sector, who had very poor living conditions, and of people who lived and worked on family farms (Fabre \& Huertas Claveria, 1980; Nadal \&Tafunell, 1992; Oliva, 1995). The neighbourhood was built between the 1950s and the 1970s to cater to the arrival of waves of workers from other regions of Spain, to the city of Barcelona. The fields and the few factories disappeared slowly to give way to a residential neighborhood. Giner et al. (1998) explained that, with the arrival of immigrants to Barcelona in the 1960s and 1970s, the metropolitan area of Barcelona had one of the highest concentrations of working-class people in Europe.

The disorder in the erection of the neighbourhood was allowed by the lax municipal laws that invited the intervention of large construction companies. Besides construction companies, there were also banks, companies, mutual insurance companies, and cooperative enterprises that built blocks for their workers or members. For instance, the company MontepíoTextil built sixteen blocks in the neighbourhood in an area now known as "the 1001 houses of the Textile". 
Blocks grew fast, but the basic infrastructures, equipment, and social services were not provided (Bogajo\&Martínez, 2010; Fabre \& Huertas Claveria, 1997).

The new inhabitants arrived at a neighbourhood that lacked the basic services and infrastructures, so they got organized and led protests to improve their living conditions. Their organization was hard to achieve. The neighbourhood had been conceived as a dormitory neighbourhood and was formed by newly arrived neighbours, so it could not be built upon existing relationships and did not have a tradition of workers' organizations, such as existed in other working-class neighbourhoods (Bogajo\& Martínez, 2010;Societatd'Estudis de la Verneda de Sant Martí, 2004).

\section{Workers' organizations as spaces of socialization}

The main finding of the discourse analysis is that the workers from the studied Spanish working classneighbourhood do not mostly reproduce the dominant economic discourses but present an alternative, leftists and pro-worker explanation for their economic situation and the economic system. This alternative discourse derives from three social movements that shaped the working-class community: the neighbourhood movement of the 1970s-1980s for the improvement of living conditions, the organized labour movement, and the resistance against the Franco dictatorship. This alternative discourse has been studied at length elsewhere. In all these originating social movements, neighbourhood organizations and neighbourhood leaders played a central role that is still remembered, glorified, and celebrated in the community. In this article, the focus will be on this particular aspect: the role of traditional workers' organizations in the shaping of workers' economic discourses.

The data analysis shows that the traditional organizations of the labour movement, such as the labour union and the workers' party, and also the neighbourhood organization, constitute a privileged space for the socialization of workers into the understanding of economic and social issues. The interviewees who had been actively involved in unions, parties or neighbourhood organizations were more confident when talking about the economy and provided more complete explanations. That is, they cited more social actors and knew how these actors were linked and what they did, and they could reflect about the economy at different geographical levels. The socializing role of traditional workers' organizations will be illustrated in this section by comparing three groups of interviewees: those who had participated in organizations of a communist character, those who had participated in other organizations, and those who had not participated in economic/social organizations. More concretely, attention will be paid to how these three groups explained the financial and economic crisis of 2007/2008 and the subsequent recession of the Spanish economy.

The discourses of all the interviewees are very similar and have many common elements that allow us to talk about a "counter-hegemonic discourse of the neighbourhood". Some common elements are the blame of the financial and economic crisis of 2007/2008 on the elites and the heavy criticism of these, the defence of the welfare state, a statement of their preference for the regulation of markets, an important dose of indignation in regard to corruption and evictions, and the expression of uncertainty towards the future. The only main difference in the interviewees' discourses is that the interviewees who had participated in organizations provided an international explanation of the crisis and blamed economic powers for the situation of the economy, whereas the other interviewees explained the crisis at the national level and blamed national politicians, at the same time that they expected these to improve the economic situation.

The first group of interviewees, constituted by interviewees who had participated in organizations with a communist background, presented the most complex explanations of the economic crisis. Their explanations were mostly situated at the international level and contemplated the financial and economic crisis as the result of the functioning of the capitalist mode of production, as well as of the intentioned actions of "the capitalists" and their organizations in the decades of the 1970s and 1980s. These interviewees cited a wide variety of actors. Besides national politicians, bankers, and executives, they mentioned international organizations such as the International Monetary Fund and the World Bank, the role of political and economic powers such as the United States, the European Union, and the past Soviet Union, as well as the role of processes such as globalization and the mechanization of production. These "communist" interviewees blamed national politicians as much as the other interviewees but they suggested that economic powers impose themselves over political powers and, therefore, there is not much national and local politicians can do to overcome the economic crisis besides not stealing public money. The explanations of these interviewees abound on Marxist terminology and explanations and fall in some occasions into economic determinism. The interviewees of the first group expected the eventual end of capitalism on the hands of the working class.

One example of the explanations of the first group is provided by José, a 79-year-old retired construction worker who had participated for many years in a neighbourhood organization and in the communist party Unified Socialist Party of 
Catalonia (PSUC), and who described himself as "leftist" and "communist".

"The United States, which want to rule the world, were the ones that used to accuse others, the Soviet Union, of expanding throughout the world. This is exactly what they're doing. And the European Union is created, but it's not created by workers but by the International Monetary Fund. Who are the International Monetary Fund? Fundamentally the rich countries: England, the United States, France... And behind these are the far-right governments, which are all over the world. Then it became globalized. What for? To defend its interests. The slogan of workers since the International: "Workers of the world, unite!" So united proletarians are accused of wanting to unite to stand for their interests, and then what does capitalism do? It makes it its own and then it gets organized internationally and all countries become involved. Why? Because capital doesn't let go of its privileges. It does it to protect its privileges, just like workers wanted to organize themselves internationally to stand for their rights. And then the economy... Who controls it? The International Monetary Fund. It tells Greece: "you're not leaving the euro, you're going to buy me money at the price that I prefer". And with this you have them caught. And what happens to Spain? Well the same, that we're stuck, just like someone who has a mortgage. [...] They're preventing workers from organizing and at the same time they're buying the management of labour unions, as they puts employers at risk of losing their privileges. They're so savage; they're so savage; capitalism is so savage that what the left is currently asking for is just jobs with a decent wage so that everyone can eat. That's what they're asking for. I mean, they're not asking for a revolution!"’

Yet another example is provided by Miguel, an 85-year-old retired construction worker. Miguel was a funding member of one of the largest Spanish labour unions and described himself as "Marxist-Leninist" and as "nothing but left".

"The crisis is internal and external. Internal of the country's production and external of what comes from abroad, because not only Spain is in crisis but we can say that the crisis is nowadays global. "Find a solution!" Well, how? If production makes wealth... but there's so much production! Why is it, that wealth is not distributed? But that they don't say. [...] This is something I understand and I think it can't be solved by each country because the crisis is not internal, just for the motives and the reasons of one country, but the issue is global. I remember an intelligent man who repeated constantly, in 1990 or so, in an election...he was a leader of United Left [political party], who said: "the issue of Maastricht". "What is Maastricht?" Maastricht is what we have. Thatcher promoted globalization and they couldn't because the working class was more organized and strong. Reagan also had an attempt of globalization but he couldn't... "But now the issue of Maastricht is here and there's globalization" - said Anguita [leader of United Left]. Thus, the issue of the crisis is not only of the Catalans, the Andalusian, the Galician, the Spaniards, it's a general crisis and if we don't find a general solution, if there isn't a big mobilization... I hoped that there'd be a big mobilization but it doesn't arrive... And if there isn't a big mobilization, the ones that have will take their wealth away as we can see every day that they are doing."

The second group of interviewees, which comprises interviewees who participated in other, non-communist organizations, presented similar explanations to those of the first group, but gave less emphasis to the capitalist economic system. They also cited fewer actors and the relationships they identified among the different actors were less clear. There is a subtle attempt in the explanations of this group to distance themselves from Marxism and from the people who belong to the first group.

The main characteristic of the second group is that, despite their active effort to abandon economic determinism, they stressed the strength of economic powers and their prevalence and imposition over political powers. In contrast with the communist group, which expected an improvement of the economic and social situation of workers in the long run, the second group is characterized by a profound pessimism as they felt that economic powers are so strong and prevalent that not even "the people" can oppose them. In contrast to the first group, they did not refer to the labour movement.

It is important to mention that, while the communist group spoke firmly about the economy, the second group qualified their statements and showed some doubts with expressions such as "I don't know much about it" or "I have no idea!" They also made clear that their statements were only an opinion with phrases such as "it's my perception" or "I believe that". The interviewees of the first group did not use these phrases, as they were sure to know how the economy really works, as opposed to the dominant economic discourses.

One example of discourse of the second group is provided by Maria, a 55-year-old educational psychologist. Maria participated in her youth in a libertarian (anarchist) athenaeum of the neighbourhood. Later in life, she supported the anarcho-syndicalistlabour union General Confederation of Labor (CGT) but she was never a unionist. At the time of the 
interview, she voted United Left or other left parties.

"Let's see, I don't believe those who have said that politicians are to blame because there's a machinery and the economy is actually what rules it, okay?, and this machinery is very perverse and strong and it really swallows you in. This is my perception. Because sometimes you say: "Well, it's those who govern, it's a neoliberal party or a left party". But there's actually a very strong machinery in the economy. The models provided have a lot of support... Let's see, either they fall, like there's a revolution, or we can hardly do this. [...] I have no idea! [Laughter] Besides reading the newspaper, listening to the radio... My profession has nothing to do with the economy! Let's see, I think that policies are conceived at the international level, eh?, and the big powers have agreements among them that have allowed a growth that has often passed over ecologic, environmental, and other issues of a minimal respect for workers. Well, all of this is happening, so how do we stop it? It's no longer a politician or a specific set of policies, everything is completely connected and involved. It's like a wheel that's very hard to break. I don't know how to explain it to you well. [...] The economy is something so important that it's what marks life. It's huge! For me it's like the maximum power, eh?, because it's above policies from one colour or another... If the same machinery goes on, I don't know where we'll get."

Yet another example is provided by Montserrat, a 56-year-old nurse. Montserrat had participated in an anarchist athenaum in her youth. She moved, however, away from anarchism and, at the time of the interview, considered selfmanagement and direct democracy to be impossible. She identified as "leftist but not radical"

"I think that there're a few families that have businesses in four things that are of great importance for humanity: food, weapons, energy... They're a basic pillar! And this is in the hands of a few families... I don't know which... Well, families and something more, right? There's that club Bilderberg, right? I don't know much about it. But it is clear that there isn't much democracy is these fields; this can't be touched. So these people force politicians to legislate so this pro-business way of functioning is not touched. Then I feel that the margin is very slim. The people of the voluntary sector are told when they do demonstrations that misery can be distributed in other ways. But it's true, in the end the only thing to distribute is destitution. I don't think they can achievemore economic or social justice this way, eh? Only the crumbs. [...] I believe that, at the small scale, you can always do things, more collective things. Or you can always stand shoulder to shoulder and do an exchange of things for free... But this is the micro-economy. The macro I think... As I've told you, it can't even be touched, not even touched. And it doesn't matter who governs, eh?, because it's not politicians who govern I think, and since the economy is at the basis, in the form of budgets. If the economy is not democratic, politics can only appear to be."

Both the communist group and the second group considered the financial crisis of 2007/2008 to be the result of the functioning of the current economic system, and of a series of political and economic decisions of the last few decades. The interviewees from these groups presented the crisis as the result of an historical process.

In contrast to the first and second groups, the interviewees of the third group provided much more simple explanations for the economic crisis. In many cases, causal explanations got entangled or substituted by first-hand descriptions of the effects of the crisis. The explanations of this group also contemplate a smaller amount of actors and the relationships among these actors are usually unknown or unclear. However, the main difference between the groups is the territorial scale in which they situate their explanation. Whereas the first and second groups provided a global explanation of the crisis, taking into account the relations between different countries as well as the role of international organizations and multinational companies, for the third group the crisis was essentially national or it affected Spain particularly. Interviewees knew that Spain belongs to the European Union but had trouble explaining how this may/may not affect the country. These interviewees also relied on the nation-state to explain the economy as if productive processes were constrained within the Spanish borders, and they expected national politicians to fix the regional and worldwide economic situation.

The interviewees of the third group considered that the crisis was mainly the result of the burst of the real estate bubble and of the corruption of the Spanish politicians, bankers, and executives. The main actor for this group was neither the economic system nor central economic powers, but national political leaders. Likewise, politicians were considered as the only ones who could do something to improve the economic situation of the country. Another recurrent topic in the interviews of the third group is mortgages.

One example of the third group's explanations is provided by Emma, a 30-year-old teacher. Emma considered herself 
"leftist but not radical" and voted for a green party.

"I think the crisis in Spain is very bad. There's crisis in other countries... Of course, at the European level we have many similar things, but I believe that in Spain it's exaggeratedly out of control. In contrast, there're other countries outside the European Union that have a better level of management of the economy and of social issues and everything is better distributed and controlled, and people have much better life standards, the quality of life is much better. I think the crisis is more national. [...] Besides, there's also all that corruption that has been discovered and no one is doing anything about it. I mean, it's something that is allowed and that even we, the people, allow, even if we see that the economy is not being managed in the way it should. The people who occupy political posts should do something and they do nothing. On the contrary, they sponge of the people and on top of that they send the money abroad and they live here in hotels that cost a lot of money per night, with all their bodyguards, going to places they shouldn't go to because they're average citizens just like us. And, on top of that, people keep voting them. They're allowing these rascals and this bad management to go on. I'm not okay with this. Then, of course, I believe there's an accumulation of badly done, and allowed, things. I don't know how we're going to make it out. In other countries this would just not happen."

Most of the interviewees in this research provided simple, national explanations as those of the third group. The number of interviewees that were able to situate Spain as a participant in an international sphere and to cite a variety of relevant actors as well as their connections was more limited. This ability is associated with the participation in traditional workers' organizations, which acted as socializing agents in regards social and economic issues. Sometimes the responses of the most able interviewees were quite ideological and unyielding, but allowed them to understand the functioning of the economy. Paradoxically, some of the most confident interviewees when discussing economic issues were elder people who did not have the chance to go to school as children. In contrast, younger interviewees with university degrees and professional jobs had more difficulty explaining the economic situation. This is due to the demobilization of workers' organizations.In fact, a young interviewee who was participating in a recent organization with a communist background provided responses similar to those of the elder people from this section in terms of complexity and security. Traditional workers' organizations, although they still inform the discourses of the workingclass people of the neighbourhood, no longer educate as many workers in the understanding of economic issues as they used to. This has left a void in the education of workers who have scarce opportunities to learn economics or discuss about the economy anywhere else.

Many interviewees and participants expressed difficulties when explaining the economic crisis and the general functioning of the economy. After almost ten years of hard economic times, most interviewees only had a very vague idea of what was going on. It is important to stress that we are not referring to the discussion of abstract economic principles but to an economic situation that has been suffered and experienced by interviewees in their daily lives for almost a decade.

\section{Demobilization of the working class}

The first three decades after the creation of the neighbourhood of La Verneda-Sant Martí in the 1950s were characterized by intense popular protests and the participation of many residents in the neighbourhood movement. In contrast to this historical organization and mobilization of the neighbours, at the time when the research was conducted, the workingclass people of La Verneda - Sant Martí were quite disorganized and there had not been important mobilizations since the start of democracy in 1982. In this section, it is argued that the presence in the neighbourhood of the generations that participated in those struggles, their control of the positions of leadership in the neighbourhood, and their recurrent use of the 1970s rhetoric and forms of organization prevented the mobilization of younger neighbours. The neighbourhood organizations, mostly composed and led by people over the age of 65, did not give way to possible new forms of organization and union. Since the Indignados Movement of 2011, there had been some attempts by newly formed teams to create new organizations and to mobilize the neighbours, but their influence in the neighbourhood was slim.

An alternative discourse of the neighbourhood, forged in three decades of struggles in the neighbourhood and the factories, prevented dominant economic discourses from becoming hegemonic in the neighbourhood and allowed working-class people to challenge these discourses and to have a more positive vision of their person and their position in the economy. However, the rejection by the younger generations of workers of the ideologies underlying this discourse, especially communism and to a lesser degree socialism, and of the "old" forms of organization, led these young neighbours to try to create new own ways of organization and mobilization, which were still very blurred and undefined. 
One of the barriers to participation mentioned by interviewees and participants was the fact that the neighbourhood organizations were most often formed by traditional manual workers who participated in the communist or socialist parties. Younger professionals and workers of the service sector who did not adhere to these ideologies felt that the neighbourhood organizations were not a good fit for them. The interviewees mentioned their frustration trying to participate in these organizations:

"I'd like to participate in the neighbourhood but I haven't found... This neighbourhood is a little bit of old warriors, neighbourhood organizations are formed by grandparents... That generation of pure and simple workers, who faced the neighbourhood struggles, had a lot of courage, eh? This was a field that became a neighbourhood! You have to recognize that, but then they are so self-important that they get stuck like in naphthalene, you know? [...] There were neighbourhood organizations of these lifelong proletarians, many people immigrated from Aragón and Andalucía... Fighters. They are very proud of achieving the subway [a neighbourhood goal] and so on, these lifelong socialist and communist fighters. There were also people more to the left...rather unconscious... more alternative... We wouldn't get involved in politics... The neighbourhood organization was too rigid." [Montserrat, 56, nurse]

José, a 79-year-old retired construction worker and a historical leader of the neighbourhood, also used the word "fighters" to describe his generation and expressed concern for the disorganized youth:

"Well, some of us are very old, the others are already gone... More than half of the fighters of my generation have already disappeared. The ones leading this fight were labour unionists and they worked on their companies defending social rights and then they kept defending them in the neighbourhood. [...] And this [demobilization] is a huge problem for society and I don't know how they're going to solve it because we're old and the future is theirs, so they have to defend it."

In some organizations, leadership was concentrated in one person whereas, in others, it was shared by a team of people. The historical leaders shared some characteristics. They were all male, manual workers, mostly immigrants from other regions of Spain, but there were also Catalan leaders. They were engaged in clandestine communist parties or the socialist party and in the organized labour movement. These leaders were praised for their very active participation in the neighbourhood, as they not only led other neighbours into mobilization but participated in the front line of all protests, even when this meant putting themselves in danger. For instance, the two historical leaders interviewed by the researcher reported having been arrested several times for participating in protests. Historical neighbourhood leaders were also praised for making the neighbourhood's problems their own.

After the first fully democratic election in 1982, the leaders' situation underwent an important change. The triumph of the Spanish Socialist Workers' Party favoured the neighbourhood leaders who were members of this party, whereas communist leaders, despite their initial strength in the neighbourhood, lost momentum. The affiliation of the neighbourhood leaders to the ruling party caused some conflicts of interest. This is how Héctor, a 43-year-old computer technician, described these processes. He denounced the way that leaders allowed themselves to be coopted:

"I joined the neighbourhood movement and people, especially those in their 40s and 50s, this generation that was twenty when the Transition started, people from the left, explained this story. They told me that, in 1979 , most of the locals who stood out for their ability to mobilize others or for their training, who were in the neighbourhood movement - which back then was stronger than the labour movement and others-, were most of them hired by the socialist Town Council. This gave them the feeling of "Well, they are one of us and they govern." But of course by joining them, and not having any trained critical element outside... Firstly, when you'd meet them, they'd have all the information and you'd have nothing. Secondly, they'd look at you like "Well, I represent the population and you don't". Furthermore, most of the people who remained in the neighbourhood movement and other movements were the people who were less trained because the others had already joined power."

José, from the quote above, also denounced cooptation. He suggested that political parties actively attempted to deactivate neighbourhood organizations:

"Nobody addresses this [the increase of drug use and drug dealing in his section of the neighbourhood], not even neighbourhood organizations. They are quiet because political parties have deactivated them. In the case of my section of the neighbourhood it's clear, right? If you want to get a job, you join a party. They disarticulate people this way, buying their need of having a job. They have disarticulated them!" 
A current leader of the neighbourhood also acknowledged this conflict of interests and expressed his loyalty to the neighbourhood, explaining how he quit his political positions in order to be able to stand for the demands of the neighbours in front of local politicians:

"I was in the executive board of a local political party. Now I'm just a member because I reached a point in which it was counterproductive to be in the neighbourhood organization and then claiming the demands of the neighbourhood to my party colleagues. They could say: "now it's not the time". Then you can't depend on that because here members are of all political colours and of all ideas, and things here are done with the group so... It was counterproductive... And in the end, I left positions that were not that important either. I have my affiliation card, which is from the left, and I'm no longer in politics." [David, 59, custodian]

Although most neighbours and participants talked about the neighbourhood organizations with great respect, some young people expressed the feeling that neighbourhood organizationswere disconnected from the current problems and needs of the neighbourhood. This is how Pablo, a 21-year-old student, explained it. His concerns are connected with the above-mentioned impression that the neighbourhood leaders had been co-opted:

"Well, I would tell you... This is private, okay?, I just want to make this clear. Don't go to the president of any neighbourhood organization because they're all politicized. Furthermore, since they've been so long in the organization... It's just like politicians, it's like they've lock themselves in their own world and they no longer see what the reality is."

Criticisms of the neighbourhood organizations and their management were mostly made very discreetly, off-record, and clearly stating that what was expressed was just a personal opinion. Furthermore, the interviewees and participants who presented their criticisms also made sure to state that neighbourhood organizations had been great for the neighbourhood in the past and even detailed some of their achievements. This shows the influence that these organizations still had in the neighbourhood.

Neighbours, however, did in some occasions confront the leaders of the neighbourhood organizations. The researcher had the opportunity to observe one of these confrontations. The dispute took place during a commemorative event. A newer president of a neighbourhood organization presented the past of the neighbourhood, putting emphasis on the achievements of the neighbourhood organizations. Then, he opened the meeting for all attendees to participate. The neighbours of the affected area expressed a long list of complains and concerns, including the lack of meetings, the unavailability of the board, and the fact that the president had not presented the accounts of the organization in years. As the attendees were getting more agitated and louder, they turned to one of the historical leaders of their area, who was attending the meeting. This elder man stressed the importance of neighbourhood organizations and neighbours' participation to take a stand for the neighbourhood in a hard economic situation and to address unmet needs of their area. His intervention, although not fully supporting the attendees, had the effect of calming them, and they left the meeting angry but quiet. This experience shows that the younger leaders of the neighbourhood (in their fifties) did not have the legitimacy and influence of the historical leaders. A quote from an elder woman summarizes some of the complaints of the neighbours:

"You saw me there because I now participate a little bit because we see some problems. The man hasn't done a meeting in seven years! He doesn't submit the accounts! This is a problem, a big one, because this has to be done every year. I can see that organizations have lost... Well, you saw it! It was a meeting for all the neighbours and how many were we? Fifteen? The memorial should have taken place here, I already told the one who's now the president of the organization. There're many elder people who can participate. If they were called, they would explain the history..." [Elena, 73, housewife and retired secretary]

Another recurrent barrier to participation in neighbourhood organizations mentioned by the working-class people of La Verneda - Sant Martí was the self-importance of some of the main traditional leaders. In fact, many interviewees and participants expressed their antipathy towards a specific leader, whose I-am-the-neighbourhood mentality prevented others from participating in neighbourhood activities. This leader was described by interviewees and participants as "a character" and a "true neighbourhood leader" who was able to "create allegiances" but also "whose way of working drove others away" [Núria, 57, shop assistant]. He was also quoted as stating: "Someone has to be in the lead and I've always led the way". This sort of comment infuriated some workers who felt that many other people besides this leader had contributed to the state of relative well-being of the neighbourhood. The following quote describes this mixed feeling of admiration and rejection: 
"He was an institution, but the problem was this kind of character. This "the neighbourhood is mine". I've seen it because when Barcelona enComú [local political party] was campaigning, Ada Colau [mayor of Barcelona] and other people came here andthey wanted to ask questions... It was the attendees turn to speak, different people could give their opinion and García, whowas there, said: "You don't need to ask, Ada, let me tell you". Can you imagine?! He thought he was the neighbourhood! And that says it all, eh? You know these people who think that all the improvements... He thought it and said it: "I've done them. I've made the improvements". Well, you and I don't know how many anonymous people behind you, right? [...] This was a person whose neighbourhood organization... the neighbourhood movement was him." [Montserrat, 56, nurse]

This quote summarizes the paradox presented in this section: the dedication and power of the traditional leaders were essential in the improvement of the neighbourhood in its first decades and these leaders still constitute a reference for the neighbourhood and are highly praised. However, this very same power and influence prevent other people from engaging in neighbourhood activities and from suggesting alternative forms of organization and mobilization that may be more suited to the current situation of the neighbourhood.

Workers also expressed rejection towards common communist positions. As we have seen in the previous section, the alternative economic explanations of the interviewees drew heavily from Marxism to contest pro-market economic discourses. However, and despite being very influenced by it, younger interviewees and participants (below 65 years old) mostly rejected traditional communist positions and rhetoric. During the field work in the neighbourhood, there was an opportunity to experience the rejection that the traditional communist rhetoric caused in middle-aged and young people.

It was a cold November evening and a meeting was held in the street by a relatively new organization with a clear communist background. Most of the attendees were above the age of 65 years. The meeting consisted of several speakers expressing their concern over the economic situation and calling to the union and mobilization of workers against the upper classes, represented by politicians, bankers, and the owners of big companies. The United States were also criticized as the main force behind neoliberalism and imperialism. The speakers repeatedly used words associated with Marxism such as "proletarians", "exploitation", and "class struggle". Between the numerous speeches, an old $\mathrm{CD}$ player with an amplifier played traditional songs of the labour movement, songs that call workers to mobilize. For instance, they played the Spanish version of the song "We Shall Not Be Moved".

As the meeting was quite loud, people passing by in the street stopped to find out what was going on. Their reactions were very informative of the level of rejection of the traditional communist rhetoric by younger neighbours. Most pedestrians ignored the meeting and continued walking. A group of men in their twenties and wearing suits walked by and laughed. Some families composed of parents and young children or teenagers had the same reaction. They stopped to check what was going on, then just smiled or laughed, and left. The laughter was neither challenging nor confrontational. Pedestrians just laughed for themselves, muttered some funny comments to their companions, and left. The traditional communist rhetoric was rejected lightly as something that had nothing to do with them.

The Indignados Movement, which started in 2011 and had a considerable presence in Barcelona, temporarily revived the neighbourhood movement in many neighbourhoods of the city. In the neighbourhood of La Verneda - Sant Martí, the Indignados Movement led to the creation of new organizations that diverged from the traditional neighbourhood organizations in their management style and in the types of activities that they organize. Pilar, a 43-year-old hairdresser, explained her engagement in a new organization following the Indignados Movement. The following quote also reflects the fact that the traditional neighbourhood organizations were failing to include the middle-aged and young neighbours:

"The Indignados Movement was like a wake-up call for many people. [...] As a result of the $15 \mathrm{M}$, an assembly was formed and I thought: "this is my chance because I identify with the $15 \mathrm{M}$ movement and I will also meet people". But I didn't know how to do it, right? Okay, I did know that there were neighbourhood organizations but I doubted, do I go there and just knock at the door? "Hi, I would like to participate"... I wasn't sure. And the $15 \mathrm{M}$ opened the doors for me. There, I met people and I found a small group of people and we more or less share similar ideas."

For many young neighbours, the Indignados Movement marked a "before and after" in their participation in social movements and civic protests, and in organizations of the neighbourhood. This occurred as they felt that their opinions and ideas were taken into account and could make a difference. Some of the newly formed organizations represented an extension of the services already provided by the traditional neighbourhood organizations to the community. Other organizations focused on including and addressing topics that were not dealt with by the traditional neighbourhood 
organizations, such as environmental concerns. These organizations and activities, however, still had a very limited influence in the neighbourhood and could not make up for the void left by the traditional neighbourhood organizations.

This situation is partially responsible for the demobilization of the working-class people of La Verneda - Sant Martí. There are other factors involved, as well, that were detected and reported by the interviewees and participants. First, interviewees reported an increase of individualism and consumerism, especially during the relative economic growth of the 1990s and early 2000s. Second, there was a decline of extra-parliamentary politics following the attainment of democracy in Spain and the transference of responsibilities to the newly achieved political system. These two processes are beyond the scope of this paper.

\section{Conclusions}

This article has argued that the traditional organizations of the labour movement, such as the labour union and the workers' party, and also the neighbourhood organization, constitute a privileged space for the socialization of workers into the understanding of economic and social issues. The participation in the organizations of a workingclass neighbourhood provides workers with the tools to critically reflect on the dominant economic discourses and to develop alternative explanations of their economic situation. These findings are in line with previous historical studies that pointed out to workers' organizations as spaces for the socialization of workers, their political education, and the reproduction of working class traditions (Hughes, 2012; Keskinen, 2011; Leberstein, 1999; Jones, 1984). Likewise, they support more recent studies that stress the importance of workers' organizations and neighbourhood organizations for the development of alternative discourses and for civic participation (Gómez et al., 2018; Martin, 2003; Wandersman et al., 1987). In contrast, the findings contradict the classic work of Burawoy (1979) as they stress the central importance of workers' organizations outside of the factory, even if they do not achieve the mobilization of workers.

The main theoretical conclusion of this article presents a paradox: the alternative explanations of the economy developed by workers and which provide them with a sense of self-respect and dignity may contribute to their demobilization and, therefore, to their maintenance of a working-class status. Counter-hegemonic discourses are empowered by the creative use of the cultural repertoires available. These repertoires should not be understood as monolithic and unchangeable but as a complex "tool kit" (Swidler, 1986) from which working-class people can pick and choose, and that is constantly adapted and interpreted based on the cultural knowledge that workers have about their community. In the neighbourhood of La Verneda - Sant Martí, the creative use of concepts historically associated with communism and anarchism to explain ones' everyday experiences as well as the combination of these concepts with other cultural repertoires was quite common. However, the present research also suggests that the ossification of neighbourhood organizations and the lack of renewal of old rhetoric, forms of leaderships, and forms of organization and mobilization lead to an immobilization of the economic alternative discourses and to a restriction of their creative use, which ultimately prevents mobilization.

More recent empirical studies yield the same results that this research. McQuarrie (2012) discovered in a case study of the civil society of Cleveland, that the mobilization of community-based organizations in the 1970s was key in securing government and charity resources during a general neighbourhood crisis in the United States' Northeast and Midwest. However, the success of these organizations had an unexpected result: the civil society became rationalized around marked-oriented values and narrow practices and it lost its creativity and capacity for change, what in turn contributed to making the neighbourhoods even more prone to foreclosures. In the same line, Pacewicz (2015) has shown that neoliberal reforms interfere in community leadership. Pacewicz explains that the organization of funding for neighbourhood organizations through competitive funding schemes and partnershipsfacilitates the emergence and successof community leaders who avoid conflict and who are flexible to market-oriented practices.

The results of this research can be extended to Spanish urban workers. The neighbourhood of La Verneda-Sant Martí is representative of the working-class neighbourhoods that surround the cities of Spain in terms of the demographic characteristics, political colour, class position, and labour status of the residents, and even similarity of the building environment. Furthermore, many of these neighbourhoods were shaped by the three historical processes that set the basis for the development of the neighbourhood counter-hegemonic discourse: the process of resistance against the Franco dictatorship, the neighbourhood movement of the 1970s, and the struggles in the organized labour movement.

\section{References}

Aglietta, M. (2015). A theory of capitalist regulation: The US experience. London: Verso.

Baran, P. A., \&Sweezy, P. M.(1966). Monopoly capital: An essay on the American economic and social order. New 
York, NY: Monthly Review Press.

Bogajo, N., and Martínez, M. (2010). Sant Martí de Provençals, de la Vila al Barri [Sant Martí de Provençals, from the Village to the Neighborhood]. Barcelona: Ajuntament de Barcelona, Districte de Sant Martí.

Bourdieu, P. (1998). Acts of resistance: Against the new myths of our time. New York, NY: Polity.

Burawoy, M. (1979). Manufacturing consent: changes in the laborprocess under Monopoly Capitalism. Chicago, IL: The University of Chicago Press.

Campbell, R. (2015). Political culture and the legacy of socialism in unified Germany. German Politics,24(3), 271-291. https://doi.org/10.1080/09644008.2015.1021793

Castells, M. (1983). The city and the grassroots. A cross-cultural theory of urban social movements. London: Edward Arnold.

Cnaan, R. A. (1991). Neighborhood-Representing Organizations: How Democratic are They? Social Service Review, 65(4), 614-634. https://doi.org/10.1086/603878

Cotgrove, S.,\&Vamplew, C.(1972). Technology, class, and politics: The case of the process workers. Sociology, 6(2), 169-185. https://doi.org/10.1177/003803857200600201

Domhoff, G. W.(2014). Who rules America? The triumph of the Corporate Rich. New York, NY: McGraw-Hill.

Fabre, J., \& Huertas Claveria, J. M. (1977). Tots elsbarris de Barcelona: Polígonsi el Districte V. 2.7, La Verneda, La Pau, El Sud-Oest del Besós, La Maresma, El Somorrostro, El Camp de la Bota, La Perona, Els NouBarris (Prosperitat, Verdum, Roquetes, La Trinitat, Torre Baró, Vallbona, La Ciutat Meridiana, La Guineueta, Canyelles), El Districte V [All the Neighborhoods of Barcelona: Industrial Estates and the District V. 2.7]. Barcelona: Edicions 62.

Fabre, J., \&J. M. Huertas Claveria. (1980). TotsbelsBarris de Barcelona: Barris que forenindependents. 1, Sant Martí de Provençals (El Clot, El PobleNou, La Sagrera) Sants, La Bordeta, Hostafranchs [All the Neighborhoods of Barcelona: Neighborhoods that Were Independent. 1]. Barcelona: Edicions 62.

Giner, S., Flaquer, L., Homs, O., \&Sarasa, S. (1998). La SocietatCatalana a la Cruïlla [The Catalan Society in the Crossroad] in S. Giner (Dir.), La SocietatCatalana [The Catalan Society] (pp.25-39). Barcelona: Institutd'Estadística de Catalunya.

Giroux, H. A. (2018). Flipping the script: Rethinking working-class resistance. Knowledge Cultures, 6(1), 10-17. doi:10.22381/KC6120182

Gómez, M., Carbonero, M. A., \&Viladrich, A.(2018).The Role of Grassroots Food Banks in Building Political Solidarity with Vulnerable People. European Societies. https://doi.org/10.1080/14616696.2018.1518537

Gough, J. (2002). Neoliberalism and Socialisation in the Contemporary City: Opposites, Complements and Instabilities. In N. Brenner and N. Theodore, Spaces of Neoliberalism. Urban Restructuring in North America and Western Europe (Pp. 58-79). Malden, MA: Blackwell Publishing.

Hakken, D. (1980). Workers' Education and the Reproduction of Working Class Culture in Sheffield, England. Anthropology \& Education Quarterly, 11(4), 211-234. https://doi.org/10.1525/aeq.1980.11.4.05x1820z

Hardt, M. \& Negri, A. (2001). Empire. Cambridge, MA: Harvard University Press.

Harvey, D.(2005). A brief history of neoliberalism. Oxford: Oxford University Press.

Jones, G. S.(1983). Languages of class: Studies in English working class history 1832-1982. Cambridge: Cambridge University Press.

Kaplan, T.(1980). Democracy and the Mass Politics of the PCE. InC. Boggs and D. Plotke, The Politics of Eurocommunism. Socialism in Transition (Pp. 103-129). London and Basingstoke: The Macmillan Press.

Karreth, A. K. (2018). Schools of democracy: How trade union membership impacts political participation in Africa's emerging democracies. Democratization, 25(1), 158-177. https://doi.org/10.1080/13510347.2017.1339273

Keskinen, L. (2011). Working-class sports clubs as agents of political socialisation in Finland, 1903-1923. The International Journal of the History of Sport, 28(6), 853-875. https://doi.org/10.1080/09523367.2011.557908

Lardín, A. (2007). RespostesObreres al Primer Franquisme (1939-1958) [Workers' Responses to the First Francoism (1939-1958)]. In J. Font, HistòriaiMemòria: El FranquismeielsSeusEfectesalsPaïsos Catalans [History and Memory: Francoism and its Effects in the Catalan Countries] (Pp. 85-106). Universitat de València\& Centre d'EstudisComarcals 
de Banyoles.

Leberstein, S. (1999). Schools of revolt: Syndicalist education and workers' culture in pre - World War I France. Paedagogica Historica, 35(1), 23-39. https://doi.org/10.1080/0030923990350103

Martín, A., \& Molina, O. (2014). ¿Por qué los afiliadossindicalestienenactitudesdiferenteshacia la inmigración? Migraciones Internacionales, 7(3), 99-131.

Martin, D. G. (2003). 'Place-framing' as place-making: Constituting a neighborhood for organizing and activism. Annals of the Association of American Geographers, 93(3), 730-750. https://doi.org/10.1111/1467-8306.9303011

McQuarrie, M. (2012). Community organizations in the foreclosure crisis: The failure of neoliberal civil society. Politics and Society, 41(1): 73-101. https://doi.org/10.1177/0032329212473087

Nadal, J., \&Tafunell, X. (1992). Sant Martí de Provençals, Pulmó Industrial de Barcelona (1847-1992) [Sant Martí de Provençals, Industrial Center of Barcelona (1847-1992)]. Barcelona: ColumnaEdicions.

Oliva Vilà, M..(1995). Els Barrisd'ADGISA: Parera, Barcelona [ADGISA's Neighborhoods: Parera, Barcelona]. Barcelona: Generalitat de Catalunya, Departament de Benestar Social.

Pacewicz, J. (2015). Playing the neoliberal game: Why community leaders left party politics to partisan activists". American Journal of Sociology, 121(3),826-881. https://doi.org/10.1086/682884.

Piketty, T.(2014). Capital in the twenty-first century. Cambridge, MA: The BelknapPress of Harvard University Press.

Scholte, J. A. (2013). Civil society and financial markets: What is not happening and why. Journal of Civil Society, 9(2), 129-147. https://doi.org/10.1080/17448689.2013.788925

Societatd'Estudis de la Verneda de Sant Martí. (2004). Records de la lluita per un barrimillor: L'associació de veïns de la Verneda Alta [Memories of the Struggle for a Better Neighborhood: Upper VernedaNeighbors' Organization]. Barcelona: Ajuntament de Barcelona, Districte de Sant Martí.

Swidler, A. (1986). Culture in action: Symbols and strategies. American Sociological Review, 51(2): 273-286.doi: $10.2307 / 2095521$

Témine, É., Broder, A., \&Chastagnaret, G. (1995). Historia de la Españacontemporánea. Desde 1808 hasta nuestrosdias. [History of Contemporary Spain. From 1808 until Our Days]. Barcelona: Editorial Ariel.

Venteo, D. (2011). Barcelona. Del Segle XVIII fins a l'actualitat. [Barcelona. From the Eighteenth Century to the Present Day]. Barcelona: Marge Books.

Wacquant, L. (2008). Urban outcasts: A comparative sociology of advanced marginality. Cambridge: Polity.

Wandersman, A., Florin, P., Friedmann, R., \&Meier, R. (1987). Who participates, who does not, and why? An analysis of voluntary neighborhood organizations in the United States and Israel. Sociological Forum, 2(3), 534-555.

Yücesan-Özdemir, G. (2003). Hidden forms of resistance among Turkishworkers: Hegemonic incorporation or building blocks for working class struggle? Capital \& Class, 7(3), 31-59. https://doi.org/10.1177/030981680308100105 